\title{
Processing of oil products by hydrocarbon-oxidizing microorganisms
}

\author{
O.M. Prishchepa \\ Doctor of geological and mineralogical Sciences, Head of department, Saint-Petersburg Mining University, \\ Saint-Petersburg, Russia \\ Y.V. Nefedov \\ PhD in Geology and Mineralogy, Associate Professor, Deputy Head of Oil and Gas Geology Department, \\ Saint-Petersburg Mining University, Saint-Petersburg, Russia
}

\section{P.A. Morgunov}

PhD in Chemisty, All-Russia Petroleum Research Exploration Institute» JSC ("VNIGRI” JSC)

\begin{abstract}
This paper presents the results of laboratory studies concerning biodegradation of oil and diesel fuel put into actions by strains of hydrocarbon-oxidizing microorganisms. The degree of biodegradation of oil and oil products in the laboratory is estimated by balance calculations, according to which the destruction could reach up to 56.6-71.6\%, while the destruction of individual fractions of the oil pollutant could exceeds $80-90 \%$. A theoretical explanation of the activity of hydrocarbon-oxidizing microorganism strains is presented.
\end{abstract}

Keywords: Hydrocarbon-oxidizing bacteria, strains of microorganisms, biodegradation of oil and oil products

\section{INTRODUCTION}

The purpose of experimental and scientific activity is to determine in the laboratory the capacity and efficiency of transformation of oil and oil products by selected strains of hydrocarbon-oxidizing microorganisms. Long-term researches of VNIGRI allowed to create a collection of microorganisms possessing high oil-oxidizing and bio emulsifying properties.

Studies of biodegradation properties of individual strains related to oil degradation are aimed for compiling a data base of microorganisms "destructors" clearing of oil (including the conditions of high concentration of oil products, in a wide temperature and $\mathrm{pH}$ range) suitable for soil and water ecosystems.

\section{PROBLEM STATEMENT}

Samples of diesel fuel and oil were selected as research objects on the hydrocarbon ecology problem. Samples of polluting oil were analyzed according to the scheme of detailed complex genuine chemical and bituminological analysis, developed and used in the laboratory practice of VNIGRI, in order to be able to compare the results in pre- and post-experimental stages.

Identification of the most active strains of hydrocarbon-oxidizing microorganisms based on the capacity to dispose of polluting oils is aimed to creating the basis of the new biological products. 
The results obtained and subsequent balance calculations based on them will allow to determine not only the activity of strains for the utilization of oil pollution in general, but also its specific fractions.

\section{OIL AND OIL PRODUCTS BIODEGRADATION BY HYDROCARBON-OXIDIZING STRAINS OF MICROORGANISMS}

In the special literature the studies about the utilization of various classes of oil hydrocarbons by pure cultures of hydrocarbon-oxidizing microorganisms devoted a significant amount of work.

Since oil and oil products are among the most common pollutants of the biosphere, the problem of cleaning the environment from oil pollution is becoming increasingly acute due to both limited possibilities (and sometimes environmental harm) of using mechanical and physic and chemical cleaning methods for these purposes. Oil is a toxin, which, covering the surface of the soil, destroys vegetation, creates conditions of oxygen starvation in the soil, has a toxic effect on humans and all living organisms, etc. Accordingly, oil, getting into the soil, changes its physical characteristics. It has brightly expressed hydrophobic properties, which are transmitted to soil particles. There are significant violations of water and air regimes of soils, leading to the development of anaerobic processes, which adversely affects soil fertility. Oil pollution causes an increase in the carbon content in the soil, leading to a high ratio of carbon to nitrogen; in addition, there is a decrease in the concentration of mobile phosphorus (Rueter et al., 1994).

Oil components, interacting with soil particles in different ways, are distributed along the vertical profile of the soil. For the vertical movement of oil down the soil section in the humus level is going high-molecular oil components, the beneath layers penetrate mostly low molecular compounds: the simplest structure of the paraffinic, naphthenic and aromatic oil hydrocarbons. On the surface of the soil oil undergoes chemical oxidation, partially photo-oxidation. However, it should be noted that abiotic oxidation is rather slow, therefore, to a greater extent the destruction of oil hydrocarbons is associated with the process of their biological oxidation, which occurs only with the participation of oil-oxidizing microorganisms.

In this regard, in recent years, more and more attention of environmentalists attracts biological method of purification from oil pollution. The method is based on the use of microorganisms capable of using oil hydrocarbons as the only source of carbon. This makes it possible to reduce the oil content to background values (the values of background concentrations vary widely depending on the area) at low operating costs and facility of decision.

\section{MECHANISMS OF HYDROCARBON OXIDATION BY MICROORGANISMS}

The processes of biogenic oxidation of hydrocarbons are so complex that currently there is not clear enough to define this mechanism. This question is complicated because the direction of the biogenic oxidation process is influenced by many factors: hydrogen potential $(\mathrm{Ph})$, oxidative-reductive potential ( $\mathrm{Rh} 2)$, temperature, lighting, osmotic pressure, etc. In addition to these factors, the physiological characteristics of the microorganisms themselves, which are obvious related to the oxidation of individual hydrocarbons and their mixtures, are also very important.

Microorganisms have the property of selective attitude to different hydrocarbons, and this capacity is determined not only by the difference in the structure of the substance, but even by the number of carbon atoms contained in the structure. For example, selected and described by V. Petrov and I. Tauch Bacterium aliphaticum and Bacterium aliphaticum liquefaciens oxidized n-hexane, n-octane, decan, hexadecan, triacontane and tetra trioctane. Bacterium paraffinicum described by the same authors, oxidized only the higher homologues of this series, starting with hexadecane. 
Oxidation of hydrocarbons by the majority of well-known microorganisms is carried out by adaptive enzymes (ferments). This fact is established by numerous experiments about the oxidation of hydrocarbons by the cells of microorganisms grown on nonhydrocarbon substrates. It has been shown, for example, that cells of heptane-oxidant bacteria grown on glucose are unable to oxidize hydrocarbons in the presence of chloramphenicol. This compound inhibits protein synthesis and thus prevents the emergence of adaptive enzymes.

Ways of microbiological oxidation of hydrocarbons are established by various methods:

- The simultaneous adaptation method proposed by R.Y. Stanier (1947) is based on the high specificity of adaptive enzymes induced by hydrocarbons to intermediate oxidation products. The basic principles of this method are: cells adapted to the oxidation of hydrocarbon are simultaneously adapted to the oxidation of subsequent intermediate products. Hence, if cells grown on hydrocarbon are simultaneously adapted to oxidation of any compound, this compound can be a member of a series of hydrocarbon metabolites.

- A method of checking the growth of microorganisms on the expected intermediate product.

The methods give the indirect evidence of metabolic pathways. Direct evidence of metabolism is obtained by the following two methods:

- Separation and determination of intermediate products of oxidation of hydrocarbons. In recent years, more advanced methods of separation and identification of products of microorganisms - gas and liquid chromatography, infrared spectrophotometry, ultraviolet rays and mass spectrometry have been used. The most accurate and reliable evidence is provided by the method of application marked by isotope substrates and mark detection in oxidation products.

- Making of enzymatic preparations out of microbial cells that catalyze specific reactions in the metabolic chain.

\section{DISPERSION OF HYDROCARBON-OXIDIZING MICROORGANISMS IN NATURE}

Microorganisms degrading hydrocarbons are widely spread in the nature. There are 22 species of bacteria, 31 species of microscopic fungi, including 19 species of yeast selected from soil ecosystems capable of biodegradation of various oil hydrocarbons. There are 25 species of hydrocarbon-degrading bacteria and 27 species of hydrocarbon-using microscopic fungi that were isolated from the marine environment.

Among them:

- bacteria (Achromobacter, Acinetobacter, Alcaligenes, Arthrobacter, Bacillus, Brevibacterium, Citrobacter, Clostridium, Corynebacterium, Desulfovibrio, Eneribacer, Escherichia, Flavobacterium, Methanobacterium, Micrococcus, Micromonospora, Mycobacterium, Nocardia, Rhodococcus, Pseudomonas, Sarcina, Serratia, Spirillum, Streptomyces, Thiobacillus, Vibrio),

- mycelial fungi (Aspergillus, Cephalosporium, Penicillium, Mucor, Fusarium, Trichoderma),

- yeast (Candida, Debaryomyces, Endomyces, Endomycopsis, Hansenula, Rhodotorula, Saccharomyces, Torulopsis, Trichosporon),

- cyanobacteriums (Agmenellum, Aphanocapsa, Lyngbya, Microcoleus, Oscillatoria, Phormidium, Plectonema).

Most hydrocarbon-oxidizing microorganisms are found both in soil and water habitats (Petrikov et. al., 2008). 


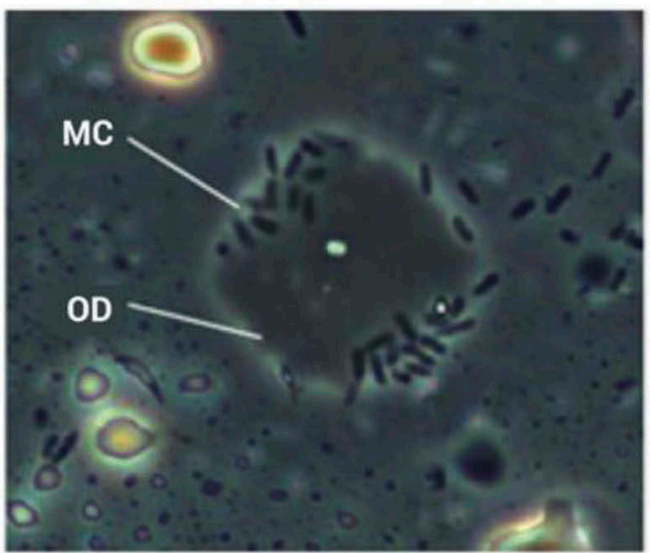

A

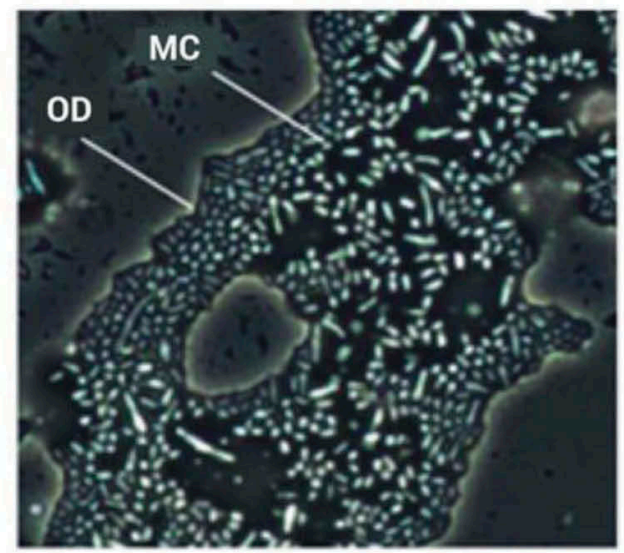

B

Figure 1. Pure cultures of microorganisms in the process of oil destruction (optical microscopy).

A - Pseudomonas putida BS3701 (pBS1141, pBS1142), B - Rhodococcus sp. S67: MC - microbe cells, OD - oil drop.

\section{OIL EFFECT ON SOIL MICROORGANISMS}

The effect of long-term impact of oil on the soil can be emerged in the change of its microbiological properties. All soils contain a large number of microorganisms capable of oxidizing various hydrocarbons. The breeding effect of oil on the soil microbiota is primarily expressed in the fact that in contaminated soils there are microorganisms using n-alkanes and aromatic hydrocarbons much more than in soils without oil. There is an increase in the number of highly specialized forms of microorganisms oxidizing gaseous hydrocarbons, solid paraffin's, aromatic hydrocarbons. The effect of oil on living organisms of the soil is largely determined by its composition and concentration. It is well known that at low concentrations oil has a stimulating effect on soil biota, as it is an energy substrate for a large group of microorganisms and contains substances that stimulate the growth of plants. On the other hand, the massive oil pollution caused by accidental spills is accompanied by an acute toxic effect of oil on living organisms (Petrikov et al., 2008).

With the help of optical microscope, the behavior of strains belonging to different species and having a different structure of the cell wall with growth in a medium with crude oil was studied. As it can be seen from Figure 1, the nature of interaction with oil gram-negative cells Pseudomonas putida BS3701 and gram-positive cells Rhodococcus sp. S67 differ significantly.

Optical studies of these cultures after three days of cultivation in medium with crude oil showed that Pseudomonas are localized on the oil drops surface, and the cells Rhodococcus are inside of oil drops (Nikulin et al., 2017).

\section{HYDROCARBONS ENTRYWAYS INTO BACTERIAL CELLS}

Today there are no reliable experimental data on the oxidation of hydrocarbons by extracellular enzymes of microorganisms. Special studies have shown that in the growth of yeast in the medium with hexadecane p. Candida enzymes responsible for the oxidation of hydrocarbons, as well as products of primary oxidation of the substrate - cetyl alcohol and palmitic aldehyde - they were contained only in cells and were not found in the culture medium. The available various data on the hydrocarbons diffusing into the cells of microorganisms, localization of hydrocarbon-oxidizing enzymes and the resulting products leave no doubt that 
hydrocarbons are oxidized intracellularly. Hence the need arises to explain the entry of waterinsoluble substrate into the cell (Gottslak, 2008).

There are the following known types of transport of hydrocarbons into the cells of microorganisms:

Passive transfer:

a) simple diffusion - a non-specific flow of substances into the cell, where various compounds penetrate the cell without interacting with any carrier;

b) facilitated diffusion - a specific process in which the transferred substance reversibly binds to the carrier located in the membrane and enters the cell in the form of a substrate-protein complex;

In this case, the rate of entry of substances is equal to the rate of its release from the cell.

Both of these processes and their speed depends on the concentration of the substrate in the medium.

Active transfer: the substance enters the cell against the concentration gradient in the medium; the process requires energy and occurs with the help of specific protein-carriers (permeases).

Further restrictions are related to the solubility of the substrate in water. The substrate can enter the microbial cell either from the state of the true solution or by its direct contact with the cell.

The absorption process is defined as active transport according to the following parameters:

- specificity with respect to the substrate; on the outer surface of the membrane formed a complex carrier-substrate;

- the need for metabolic energy; the carrier has a high affinity for the substrate, if it is facing the outer surface of the membrane, and low affinity to it, if it is facing its inner surface. These changes in the carrier consume metabolic energy;

- transport of the corresponding substrate against the concentration gradient; this is due to a change in the affinity of the carrier to the substrate during the transition from outside to inside;

- release of unmodified substrate into cytoplasm (as opposite to group transfer) (Skryabin, G. K., 2008).

Only low molecular weight liquid hydrocarbons from $\mathrm{C} 5$ to $\mathrm{C} 11$, as well as some aromatic hydrocarbons, can slightly dissolve in water, higher molecular weight homologues are practically insoluble (Gottslak, 2008).

\section{MICROBIOLOGICAL OXIDATION OF OIL HYDROCARBONS AND OIL PRODUCTS}

Microbiological transformations of hydrocarbons are a special area because of some features of these processes. Their specificity is due to the peculiarity of hydrocarbons as chemical compounds with the maximum recovery associated with these hydrophobic properties. It turned out that the hydrophobicity of the hydrocarbon molecule is of great importance for the chemistry of microbiological oxidation of these compounds, their transport to the microbial cell, the dynamics of culture growth, their physiology, and many aspects of the processes technology associated with the use of hydrocarbon substrates.

All reactions of microbiological transformation of hydrocarbons are oxidation reaction. The limiting recovery of these substances makes it necessary for their oxidation the presence of oxygen. The hydrophobic nature of the molecule is the reason that the oxidation processes are carried out by oxygenases, in contrast to the oxidation of more hydrophilic substances that occur under the action of dehydrogenases. The hydrophobicity of hydrocarbon substrates and their poor solubility in water determine the methods of transport of substances into the cell, that was discussed above (Petrikov et. al., 2008). 
A characteristic feature of the process of assimilation of hydrocarbons as a carbon source is the frequent accumulation of intermediate products in the culture medium of microorganisms growing due to such substrates (Nikulin, A., Epifancev, K. 2017).

Let us consider these processes by the example of normal paraffins oxidation. The ways of oxidation of normal paraffins by microorganisms using these compounds as sources of carbon and energy were studied in sufficient detail.

In the vast majority of cases, as a result of the primary enzymatic attack of the n-paraffin molecule, the oxidation of the terminal carbon atom occurs.

The first stable products of oxidation of hydrocarbons are primary alcohols. The next stage is the usual biological transformation of alcohol into aldehyde and aldehyde into acid. The general scheme of reaction is as follows.

\section{$\mathrm{R}-\mathrm{CH} 2-\mathrm{CH} 3+[\mathrm{O}] \quad \mathrm{R}-\mathrm{CH} 2-\mathrm{CH} 2 \mathrm{OH}-2 \mathrm{H} \quad \mathrm{R}-\mathrm{CH} 2-\mathrm{CHO}-2 \mathrm{H}+\mathrm{HOH} \quad \mathrm{R}-\mathrm{CH} 2-\mathrm{COOH}$}

The further mechanism of fatty acids assimilation, arising during hydrocarbons oxidation, proceeds by $\beta$-oxidation, which consists in successive spliting of two-carbon fragments in the form of active acetate entering the tricarboxylic acid cycle.

Further reduction of fatty acid formed as a result of microbiological oxidation of n-alkanes along with classical $\beta$-oxidation may include a number of minor products:

1) $\omega$-hydroxylation, leading to the formation of $\omega$-oxycarboxylic acids, and then dicarboxylic acids with further partitioning. This oxidation way has been experimentally proven in many microorganisms;

2) $\alpha$-oxidation, decarboxylation, which is proven in cases where the carbon subterminal atom carries a ketogroup or hydroxyl; 3) dehydrogenation of fatty acid followed by oxidative cleavage of the double bond. The existence of this mechanism is suggested by a group of researchers (W.R. Finnerty, R.E. Kallio, 1964).

The terminal oxidation mechanism described above is not the only way to degrade n-alkanes. In some microorganisms, the oxidation of subterminal or internal carbon atoms is described, which leads to the formation of secondary alcohols and ketones. This way sometimes goes as a minor along with terminal oxidation.

H.B. Lukins and J.W. Foster (1963) found that some mycobacteria metabolize n-alkanes through methylketone with the intermediate formation of peroxide and secondary alcohol. Further oxidation of ketones has not been sufficiently studied. In the experiments of J.R. Vestal and J.J. Perry (1969) Brevibacterium sp. was oxidized propane through acetone with subsequent attack on the terminal methyl and decarboxylation:

$\mathrm{CH} 3 \mathrm{CH} 2 \mathrm{CH} 3 \rightarrow \mathrm{CH} 3 \mathrm{CHOHCH} 3 \rightarrow \mathrm{CH} 3 \mathrm{COCH} 3 \rightarrow \mathrm{CH} 3 \mathrm{COCH} 2 \mathrm{OH} \rightarrow \mathrm{CH} 3 \mathrm{COOH}$

Based on the works of F.W. Forney and A.J. Markovetz (1970) the degradation of tridecane by culture of Pseudomonas aeruginosa appears to be as follows:

$\mathrm{CH} 3(\mathrm{CH} 2) 11 \mathrm{CH} 3 \rightarrow \mathrm{CH} 3(\mathrm{CH} 2) 10 \mathrm{CHOHCH} 3 \rightarrow \mathrm{CH} 3(\mathrm{CH} 2) 10 \mathrm{COCH} 3 \rightarrow$ $\mathrm{CH} 3(\mathrm{CH} 2) 9 \mathrm{CH} 2 \mathrm{OCOCH} 3 \rightarrow$

$\mathrm{CH} 3(\mathrm{CH} 2) 9 \mathrm{CH} 2 \mathrm{OH}+\mathrm{CH} 3 \mathrm{COOH}$

$\downarrow$

$\mathrm{CH} 3(\mathrm{CH} 2) 9 \mathrm{COOH}$

\section{BIOGENIC OXIDATION OF OILS OF DIFFERENT CHEMICAL COMPOSITION}

In the process of oil oxidation, the mutual influence of hydrocarbon and non-hydrocarbon components included in its composition plays an important role (Khotimskii et. al., 1970).

With anaerobic and aerobic microbial destruction, regardless of the type of oil, their density increases, the content of resinous-asphaltene compounds, sulfur increases and the concentration of paraffin hydrocarbons in the system decreases. The residual accumulation of naphthenic hydrocarbons was noticed (Bruheim et al., 1998).

Reduction of paraffin potential of oils in biochemical oxidation is due to the removal of model systems of $\mathrm{n}$-alkanes as substances mainly consumed by microorganisms. Among n-alkanes, bacteria are better able to absorb low molecular weight compounds, which has 
Table 1. The classification of the components of the oils according to their capacity to biodegradation.

\begin{tabular}{|c|c|c|c|}
\hline Group & $\begin{array}{l}\text { Attitude to the } \\
\text { microorganism } \\
\text { effects }\end{array}$ & $\begin{array}{l}\text { Degree of biodegradation, } \\
\% \text { to the original content }\end{array}$ & Oil components \\
\hline I & Highly sensitive & $80-100$ & $\mathrm{n}$-alkanes; isoalkane \\
\hline II & Sensitive & $60-80$ & $\begin{array}{l}\text { cycloalkanes with } 6,1,5 \text { and } 2 \text { rings; } \\
\text { s-aromatics; monoaromatic }\end{array}$ \\
\hline III & $\begin{array}{l}\text { Moderately } \\
\text { sensitive }\end{array}$ & $45-60$ & $\begin{array}{l}\text { cycloalkanes with } 3 \text { and } 4 \text { rings; three } \\
\text { aromatic hydrocarbons }\end{array}$ \\
\hline IV & Resistant & $30-45$ & $\begin{array}{l}\text { tetra-aromatic hydrocarbons; sterane; } \\
\text { triterpene; naphtene aromatic } \\
\text { hydrocarbons }\end{array}$ \\
\hline V & Highly resistant & $0-30$ & $\begin{array}{l}\text { pentha-aromatic hydrocarbons; asphal- } \\
\text { tenes; resins }\end{array}$ \\
\hline
\end{tabular}

been proven on the range of $\mathrm{C} 14$ to $\mathrm{C} 20$ hydrocarbons. In addition, no selectivity has been found in the biooxidation of hydrocarbons with an even or uneven number of $\mathrm{C}$ atoms in the molecule (Bruheim et al., 1998).

From the physiological characteristics of each kind of microorganisms depends on the direction of the process of destruction of individual hydrocarbons and their mixtures with different degrees of resistance to oxidation (Table 1).

The above-mentioned, undoubtedly complicates obtaining unambiguous results of research of predictability of transformation of various classes of oils. However, oil microbiology has research works, in the results of which can be traced geochemical changes in the composition of oils during biodegradation.

In 1960-1970-ies in "VNIGRI" JSC under the guidance of doctor of biological sciences T. L. Simakova were conducted long-term comprehensive studies of the change pecularities of different chemical composition of oils, some of their fractions and individual hydrocarbons in

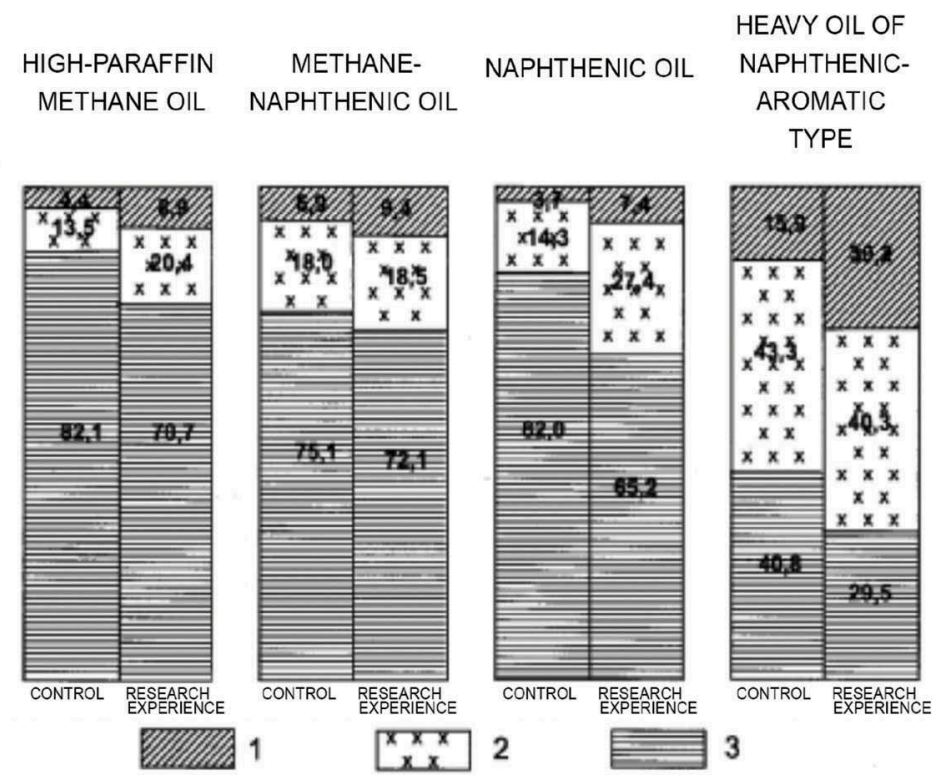

Figure 2. Changes of the chemical group composition of oils under the influence of biogenic factor. 1 - asphalt-resinous components; 2 - aromatic hydrocarbons; 3 - methane and naphthenic hydrocarbons. 
biodegradation. Biocenoses of microorganisms were isolated from formation waters of the same wells, from which oil was selected for experiments.

As a result of these studies on a large factual material, it was shown that as a result of biogenic oxidation in aerobic conditions, there are significant changes in the group hydrocarbon composition of oils, leading to the transition of one geochemical type of oil to another (Skryabin, G. K., 2008)., (Figure 2).

The authors came to the following main conclusions (Khotimskii et. al., 1970):

- High-paraffin methane oil under the influence of microorganisms becomes heavier, its viscosity and the content of asphalt-resinous substances increase, the content of solid paraffins decreases. In the group hydrocarbon composition, it is redistributed in the content of separate groups of hydrocarbons with a decrease in the amount of methane (normal and isostructure), as well as aromatic hydrocarbons that are part of the kerosene fractions. The total content of naphthenic and aromatic hydrocarbons in oil as a whole increase. Thus, methane oils under the influence of the biogenic factor change with the approach to the methane-naphthenic type.

- Methane-naphthenic oil type under the influence of the biogenic factor changes in the same direction, as a result of which it is weighted, it also increases the content of asphalt-resinous substances, the number of saponification due to the ethereal number and the number of solid paraffins decreases. Its hydrocarbon composition changes, as in methane oil, with a decrease in the amount of methane hydrocarbons and aromatic hydrocarbons, but the last one is only in kerosene fractions. In general, methane-naphthenic oils change with increasing content of naphthenic and aromatic hydrocarbons in their composition.

- Naphthenic oil type with a high content of naphthenic hydrocarbons under conditions of biogenic oxidation changes with increasing specific gravity, viscosity, content of asphaltresinous components and acid number in oils. Its hydrocarbon composition reduces the content of methane and naphthenic hydrocarbons. In contrast to the above types of oils, the amount of aromatic hydrocarbons included in the composition of kerosene fractions increases. Thus, as a result of the vital activity of microorganisms, the oxidation of naphthenic oil is accompanied by an increase in its aromatic fraction and a decrease in methane and naphthenic hydrocarbons.

- Oxidation of heavy oil of naphthenic-aromatic type is accompanied by its tarring with a significant increase in specific gravity and viscosity. Unlike other types of oils studied by the authors, as a result of biogenic oxidation in oils of naphthenic-aromatic oil, both acid and ethereal number increases. The hydrocarbon composition of this oil reduces the content of all groups of hydrocarbons: methane, naphthenic and aromatic - by increasing the asphalt-resinous components.

According to the above, during biodegradation of the studied types of oils in their group composition, there are serious changes: the relative content of the asphalt-resinous components increase in 1.4-2 times, aromatic hydrocarbons increases in 1.02-1.9 times (the exception is naphthene-aromatic oil). The relative content of methane and methane-naphthenic hydrocarbons, compared with the control, is reduced in 0.12-1.4 times.

Changes in the group composition of oils should be taken into account in the development of technology for cleaning soils from oil pollution.

The practical help of oil microbiology in solving this problem is the allocation of pure cultures of hydrocarbon-oxidizing microorganisms, the establishing of their origin and the degree of activity in the oxidation of oils and oil products.

The most active strains of hydrocarbon-oxidizing microorganisms, oxidizing to a large extent resistant to biodegradation components of oil, are the most promising for the creation on their basis of biological products for soil purification from oil pollutant.

The study of the ability of microorganisms to oxidize specific classes of hydrocarbons in the composition of oils, as shown above, allows to create biological products for the purpose in the future. 


\section{LABORATORY RESEARCH ABOUT OIL BIODEGRADATION BY STRAINS OF HYDROCARBON-OXIDIZING MICROORGANISMS}

In the study of oil utilization activity, as noted above, 9 strains of HOM were involved in laboratory experiments. Series of experiments with oil was carried out at a temperature of $280 \mathrm{C}$ on the laboratory shaker for 12 days. This regime was conditioned by the time frame for research. Extraction conditions of post-experimental samples differed from the conditions for pre- experimental samples. Chloroform, as in post-experimental samples with diesel fuel, extracted residual oil and culture medium (containing microbial mass and intermediate products of bio-oxidation of oil). Then the chloroform extracts were combined and on full complex chemical bitumen analysis the total extract was coming, chloroform bitumoid (CHB), which is actually not recycled oil and the residual products of its oxidation. This allowed without preliminary calculations to immediately assess the loss of oil as a whole and its individual fractions, which, in fact, is provided by the objectives of the planned research (Nikulin et al., 2017).

Consideration of the results of the analysis of CHBDF and CHBCM of bio-oxidized diesel fuel showed that these data are of interest from the point of view of the physiology study of hydrocarbon-oxidizing microorganisms, the study of this direction is out of this research topic (Saitgaleev et al., 2019).

The selected mode of laboratory experiments and analytical data on oil utilization allow us to compare the tested strains of HOM on the ability to oil dispose under specified conditions and select the most active.

The main parameters of experiments on oil utilization by the studied strains: a charge of oil is $1.45-2.02 \mathrm{~g} / 100 \mathrm{ml}$, or $14500-202000 \mathrm{mg} / \mathrm{l}$. This is a fairly high oil contamination. HOM is in the range of (0.80-5.30) 108 cells $/ \mathrm{ml}$. After 12 days in post-experimental samples the $\mathrm{pH}$ of the culture medium remained at pre-experimental level or increased to 7.5 - 8.0. Decrease of pH was not recorded (Sukplanga et al., 1999).

Table 2 shows the change in qualitative composition of crude oil in post-experimental samples of studying the activity of utilization of the tested strains of HOM. As it follows from the table, there were some changes in the qualitative composition of oils within 12 days. In the initial experiments samples the content of oils was $69.98 \%$. In the post-experimental samples the oil content varies from 63.76 to $70.67 \%$, that is, in the qualitative composition of the postexperimental samples there is a decrease in the oil content ( 7 strains of HOM), and its increase (2 strains $-1-\mathrm{R}$ and $99-\mathrm{T})$.

Table 2. Changes in oil composition (\% rel.) in experiments on the study of the biodegradation activity of hydrocarbon-oxidizing microorganisms (the duration of experiments is 12 days).

\begin{tabular}{|c|c|c|c|c|c|c|c|c|c|c|}
\hline \multirow{3}{*}{$\begin{array}{l}\text { Strain } \\
\text { HOM in } \\
\text { experiments }\end{array}$} & \multicolumn{4}{|c|}{ Group composition of bitumoid, $\%$} & \multicolumn{4}{|c|}{ Hydrocarbons oils composition, $\%$} & \multirow{3}{*}{$\begin{array}{l}\frac{\text { Sat. }}{\mathrm{HC}} \\
\frac{\mathrm{Ar}}{\mathrm{HC}}\end{array}$} & \multirow[b]{3}{*}{ HOM type } \\
\hline & \multirow[b]{2}{*}{ oils } & \multirow[b]{2}{*}{$\begin{array}{l}\text { benz. } \\
\text { resins }\end{array}$} & \multirow{2}{*}{$\begin{array}{l}\text { sp./ } \\
\text { benz. } \\
\text { resins }\end{array}$} & \multirow[b]{2}{*}{ asphaltene } & \multirow[b]{2}{*}{$\begin{array}{l}\text { saturated } \\
\text { hydrocarbons }\end{array}$} & \multicolumn{3}{|c|}{$\begin{array}{l}\text { Aromatic } \\
\text { hydrocarbons }\end{array}$} & & \\
\hline & & & & & & Ar I & Ar II & $\begin{array}{l}\text { poly- } \\
\text { Ar }\end{array}$ & & \\
\hline Initial oil & 69,98 & 14,08 & 11,80 & 4,14 & 50,76 & 17,52 & 21,15 & 10,57 & 1,03 & - \\
\hline 4-D & 67,59 & 13,92 & 13,12 & 5,37 & 51,51 & 20,61 & 18,79 & 9,09 & 1,06 & Pseudomonas \\
\hline $12-\mathrm{R}$ & 63,76 & 14,34 & 16,86 & 5,04 & 50,46 & 20,31 & 24,00 & 5,23 & 1,02 & Pseudomonas \\
\hline $1-K P$ & 68,66 & 13,57 & 12,38 & 5,39 & 54,71 & 12,76 & 28,27 & 4,26 & 1,21 & Rhodococcus \\
\hline $1-\mathrm{R}$ & 70,65 & 11,96 & 13,04 & 4,35 & 47,63 & 23,66 & 14,20 & 14,51 & 0,91 & Pseudomonas \\
\hline $2-\mathrm{V}$ & 69,40 & 13,80 & 11,40 & 5,40 & 51,34 & 19,76 & 16,22 & 12,68 & 1,05 & Pseudomonas \\
\hline $99-\mathrm{T}$ & 70,67 & 11,81 & 13,19 & 4,33 & 47,73 & 22,16 & 17,04 & 13,07 & 0,91 & Pseudomonas \\
\hline $4-G$ & 66,14 & 13,94 & 13,35 & 6,57 & 48,15 & 25,00 & 16,36 & 10,49 & 0,93 & Mycobacterium \\
\hline 1-SH & 67,00 & 14,80 & 13,60 & 4,60 & 55,38 & 16,31 & 15,69 & 12,62 & 1,24 & Mycobacterium \\
\hline $48-\mathrm{U}$ & 65,88 & 15,58 & 14,40 & 4,14 & 50,90 & 22,75 & 19,16 & 7,19 & 1,04 & Pseudomonas \\
\hline
\end{tabular}


Similar changes occurred in the content of other fractions of post-experimental bitumoids, comparing with the original oil. It is almost impossible to make a certain predictability in the change of oils during biodegradation based on the results of the study of the qualitative composition (Nikulin et al., 2017).

Somewhat greater certainty in the characteristic of this process makes the ratio of saturated hydrocarbons to aromatic hydrocarbons. According to the deviation of the value of this ratio, comparing with that in the original oil, the tested strains can be divided into two groups. In case of oil biodegradation by one group of strains, the value of this ratio, in comparison with the original oil, it decreases, and in case of destruction by another group of strains - it increases (Dashko et al., 2016).

It is possible to evaluate and compare the activity of the tested strains of HOM only after carrying out the balance calculations of the processes of utilization in the conditions of laboratory experiments with oil and its specific fractions. Remaining oil in every experience and qualitative composition of post-experimental samples allowed to make balance calculations of the process of oil utilization by tested strains and to find loss of oil in whole and in its separate fractions in the weight \% relatively to the content of their source in the sample (Table 3).

According to the table, oil losses in these experiments are $1.4-73.4 \%$ of its original components. The loss of specific fractions in the composition of the oil is the following: oil 5.0 to $75.8 \%$, benzene resin 2.4-72.9\%, alcohol benzene resin 9.0-62.0\%, asphaltenes $17.0-67.6 \%$. There were losses in the fractional composition of oils: the content of saturated hydrocarbons decreased by $2.8-75.9 \%$, Ar I $-12.8-71.9 \%$, Ar II $-14.1-72.5 \%$, poly Ar $-1.0-88.0 \%$ relative to their initial content (Dashko et al., 2016).

The following fact is noteworthy. During oil biodegradation in the specified conditions of the experiments, a significant formation of intermediate products was recorded, which, according to their chemical characteristics, were analytically established in the fractions of oils (strain 1-R), resins and asphaltenes of the group composition of CHB and in the fractions of saturated hydrocarbons (strains 1-KP and 1-SH) and aromatic hydrocarbons in the oils. In the post-experimental samples of strains $48-\mathrm{U}$ and $1-\mathrm{R}$ the amount of remaining oil exceeds the initial sample weight.

Additionally, the calculations of oil losses in whole and oils fractions (strain 99-T) excluding new formations were carried out. In this case, as shown by calculations, the losses during the experiments of oil in whole and oil fractions increased. Based on the results of the study of the

Table 3. Loss of oil in experiments on the biodegration activity of hydrocarbon-oxidizing microorganisms (the duration of experiments is 12 days).

Loss, weight $\%$ relative to the specific initial oil fraction

\begin{tabular}{|c|c|c|c|c|c|c|c|c|c|c|}
\hline \multirow[b]{2}{*}{ Strain HOM } & \multirow[b]{2}{*}{ Oil in whole } & \multirow[b]{2}{*}{ Oils } & \multirow[b]{2}{*}{ benz. $\mathrm{cm}$. } & \multirow{2}{*}{$\begin{array}{l}\mathrm{sp} / \\
\text { benz. } \\
\mathrm{cm} .\end{array}$} & \multirow[b]{2}{*}{ Asph. } & \multicolumn{4}{|c|}{ In oils } & \multirow[b]{2}{*}{$\begin{array}{l}\text { HOM } \\
\text { type }\end{array}$} \\
\hline & & & & & & $\mathrm{HC}$ & Ar I & Ar II & $\begin{array}{l}\text { poly } \\
\text { Ar }\end{array}$ & \\
\hline $12-\mathrm{R}$ & 73,4 & 75,8 & 72,9 & 62,0 & 67,6 & 75,9 & 71,9 & 72,5 & 88,0 & Pseud. \\
\hline $99-\mathrm{T}$ & 20,7 & $19,9 / 20,2$ & 33,5 & 11,4 & 17,0 & 24,7 & $+1,3$ & 35,5 & 1,0 & Pseud. \\
\hline 4-D & $5,6 / 7,1$ & $\overline{8,9 / 10} 0,1$ & 6,7 & $+5,0$ & $+22,5$ & 7,5 & $+7,2$ & 19,0 & 21,6 & Pseud. \\
\hline $2-\mathrm{V}$ & $5,8 / 6,8$ & $6,6 / 8,8$ & 7,7 & 9,0 & $+22,9$ & 5.6 & $+5,2$ & 28,4 & $+11,9$ & Pseud. \\
\hline 1-SH & $\overline{2,1} / 4,4$ & $\overline{6,3} / 8,7$ & +2.9 & $+12,8$ & $+8,7$ & +2.2 & 12,8 & 30,5 & $+11,9$ & Myc. \\
\hline $1-K P$ & $3,1 / 4,4$ & 5,0 & 6,7 & $+1,6$ & $+26,2$ & $+2,4$ & 30,8 & $+27,0$ & 61,7 & Rhod. \\
\hline $4-G$ & $\overline{1,4} / 5,1$ & 6,8 & 2,4 & $+11,5$ & $+56,5$ & 11,6 & $+32,9$ & 28,0 & 7,6 & Myc. \\
\hline 48-U & $\overline{ \pm 0}, 7 / 3,7$ & 5,2 & $+11,4$ & $+22,9$ &,+ 07 & 5,0 & $+23,1$ & 14,1 & 25,5 & Pseud. \\
\hline $1-\mathrm{R}$ & $\pm \overline{2,3} / 4,4$ & $\pm \underline{3,6 / 11,4}$ & 12,9 & $+13,3$ & $+7,8$ & 2,8 & $+39,8$ & 30,5 & $+42,2$ & Pseud. \\
\hline
\end{tabular}


activity of oil utilization in laboratory experiments, the most active strain is $12-\mathrm{R}$, the strain 99-T is noticeably worse in activity (Kotiukov et al., 2019).

Other tested strains did not show their activity in these experiment conditions. Disposal of oil in whole it amounted to 3.7-7.1\%, oils 5.0 to 10.1 per cent (excluding new formations). But these strains showed quite high activity in the utilization of aromatic hydrocarbons in oils (up to $61.7 \%$ - strain $1-\mathrm{KP}$ ).

\section{CONCLUSIONS}

The degree of biodegradation of oil is evaluated by balance calculations under laboratory experiments. According to calculations, in general utilization makes 56.6 and $71.6 \%$. Utilization of separate fractions of oil pollutant exceeds $80-90 \%$. The theoretical substantiation of activity of hydrocarbon-oxidizing strains of microorganisms on utilization of oil and oil products is given.

\section{REFERENCES}

Bruheim P., Eimhjellen K. Chemically emulsified crude oil as substrate for bacterial oxidation: differences in species response // Canadian Journal of Microbiology. - 1998. -Vol. 44(2). - p. 195-204.

Dashko, R., Karpova, Y. Engineering geology and geotechnics of fractured clays as building base and surrounding medium (by the example as clayey bedrocks in Saint-Petersburg) (2016) International Multidisciplinary Scientific GeoConference Surveying Geology and Mining Ecology Management, SGEM, 3, pp. 85-92.

Dashko, R. E., Kotiukov, P.V. Fractured clay rocks as a surrounding medium of underground structures: The features of geotechnical and hydrogeological assessment (2018) Geomechanics and Geodynamics of Rock Masses, 1, pp. 241-248.

Nikulin, A., Nikulina, A.Y. 2017. Assessment of occupational health and safety effectiveness at a mining company. Ecology, Environment and Conservation, 23(1), pp. 351-355.

P. V. Kotiukov, I. Yu. Lange, Engineering Geological Analysis of the Landslide Causes During the Construction of Industrial Building, International Journal of Civil Engineering and Technology 10(4), 2019, pp. 316-323. http://www.iaeme.com/IJCIET/issues.asp?JType=IJCIET\&VType=10\&IType $=4$

Rueter P., Rabus R., Wilkest H., Aeckersberg F., Rainey Fred A., Holger W. Anaerobic oxidation of hydrocarbons in crude oil by new types of sulphate-reducing bacteria//Nature. - 1994. -Vol. 372. - p. 455-458.

Saitgaleev, M., Senchina, N., Sokolova, J. 2019. Application of the method of ion-selective electrodes in exploration work on the sea shelf. Marine Technologies 2019, Gelendzhik. DOI: 10.3997/22144609.201901811

Sukplanga P., Thongmeea A., Velaa G. Roland. Degradation of Linseed Oil Vapors by Soil Bacteria in Trickling Biofilters / / Bioremediation Journal. - 1999. -Vol. 3. - p. 189-200.

The study of the survival of microorganisms-oil destructors of Pseudomonas and Rhodococcus with different storage methods

K. V. Petrikov, T. V. Yakshina, E. P. Vlasova, etc. // Materials of worldwide conference "Current state and prospects of Microbiology and biotechnology". Minsk, June 2-6, 2008. 223-225 pp. 